\title{
PROFIL PENDERITA DENGAN TUMOR PAYUDARA YANG DIBIOPSI DI RUMAH SAKIT SILOAM MRCCC SEMANGGI PADA TAHUN 2017-2018
}

\author{
Fajar Lamhot Gultom, Gupita Widyadhari, Yonathan Nanda Gogy \\ Fakultas Kedokteran Universitas Kristen Indonesia, Jakarta
}

Email : fajar.gultom@uki.ac.id

\begin{abstract}
ABSTRAK
Pendahuluan: Benjolan payudara merupakan jaringan lain yang tumbuh di dalam payudara yang berisikan massa/lemak/cairan, dan merupakan dampak dari perubahan fisiologis tubuh yang dapat berupa tumor jinak, tumor ganas, dan hiperplasia payudara. Namun, Indonesia belum ada data yang lengkap mengenai angka kejadian FAM. Tujuan: Mengetahui bagaimana profil penderita dengan tumor payudara yang dilakukan biopsi di Rumah Sakit Siloam MRCCC Semanggi pada tahun 2017-2018, mengetahui jenis benjolan payudara, dan jumlah tumor jinak dan ganas di Rumah Sakit Siloam MRCCC Semanggi. Metode: Desain penelitian merupakan penelitian deskriptif dengan studi retrospektif, dengan melihat data hasil laboratorium pasien yang melakukan pemeriksaan sitologi dan histopatologi. Metode total sampling dalam cara memilih sampel. Dari total keseluruhan, diambil 304 sampel berdasarkan kriteria inklusi dan eksklusi. Hasil Penelitian: Penelitian dilakukan terhadap pasien Rumah Sakit Siloam Semanggi pada tahun 2018. Seluruh data dijelaskan dalam umur, jenis kelamin, jenis pemeriksaan, dan diagnosis. Kesimpulan: Berdasarkan hasil penelitian dapat disimpulkan bahwa, tumor ganas terbanyak yaitu karsinoma mammae dengan jumlah $201(66,1 \%)$ pada rentang usia 40-59 tahun. Tumor jinak terbanyak yaitu FAM dengan jumlah $83(27,3 \%)$ pada rentang usia 20-39 tahun. Non neoplasma terbanyak yaitu mastitis dengan jumlah 20 (6,6\%) pada rentang usia 30-39 tahun. Pemeriksaan terbanyak untuk mendiagnosis benjolan pada payudara adalah histopatologi dengan sediaan lumpektomi.
\end{abstract}

Kata Kunci: Profil, Benjolan payudara, neoplasma jinak, non neoplasma jinak.

\begin{abstract}
Breast lumps are other tissues that grow in the breast that contain mass/fat/fluid, and are the result of physiological changes in the body that can be in the form of benign tumors, malignant tumors, and breast hyperplasia. Based on the Indonesian report, there is no complete data regarding the incidence of FAM. To find out the profile of the breast tumor biopsy at the Siloam MRCCC Semanggi hospital in 2017-2018, the types of breast lumps that were biopsied and the number of benign and malignant tumors at Siloam MRCCC Semanggi hospital. The study design was a descriptive study with a retrospective study, by looking at the laboratory data of patients who performed stiology and histopathological examinations. How to total sampling method in how to select samples. Of the total, 304 samples were taken based on inclusion and exclusion criteria. The study was conducted on patients at Siloam Semanggi Hospital in 2018. All data were explained in terms of age, gender, type of examination, and diagnosis. Based on the results of the study, that the most malignant tumor is mammary carcinoma with a total of $201(66.1 \%)$ in the age range of 40-59 years. The most benign tumors were FAM with a total of $83(27.3 \%)$ in the age range of 20-39 years. The most non-neoplasm is mastitis with a total of $20(6.6 \%)$ in the age range of 30-39 years. The most examination to diagnose lumps in the breast is histopathology with lumpectomy preparations.
\end{abstract}

Keywords : Profil, Breast lumps, benign neoplasms, benign non neoplasms. 


\section{PENDAHULUAN}

Payudara atau mammae merupakan suatu bagian tubuh yang terdiri atas jaringan lemak, kelenjar fibrosa, dan jaringan ikat yang terhubung ke otot-otot dinding dada. ${ }^{1,2}$ Namun pada proses fisiologis tubuh, terdapat beberapa faktor yang menyebabkan sel-sel pada payudara mengalami perkembangan yang tidak normal. Perubahan fisiologis tersebut menimbulkan benjolan pada payudara yang berupa tumor jinak, tumor ganas, dan hiperplasia payudara. Faktor tersebut dapat berasal dari dalam tubuh berupa genetik, perubahan hormon, penumpukan cairan, dan yang berasal dari luar tubuh berupa penggunaan steroid yang berlebih, penggunaan pil KB sebelum waktunya, penumpukan bakteri dan efek samping dari radioterapi. ${ }^{2}$

Diagnosis dalam stadium lanjut tumor payudara menyebabkan berkurangnya pilihan terapi dan makin kecil kesempatan keberhasilan terapi. Hal ini menyebabkan makin tingginya angka kematian akibat tumor payudara. Penting mengetahui profil penderita tumor payudara di sebuah rumah sakit agar dapat mengetahui jenis tumor jinak maupun ganas pada payudara yang sering terjadi hingga mengetahui permasalahan yang terjadi pada tumor payudara itu sendiri.

Tumor ganas payudara di negara berkembang dalam stadium lanjut bila dibandingkan dengan tumor ganas payudara di negara maju. Dijelaskan pada tahun 2020 kasus baru kanker pada payudara mencapai 298.445 dari 2.252.981 kasus tumor ganas di Asia Tenggara. Globocan mencatat kasus baru kanker payudara di Indonesia sebanyak 65.858 pada tahun 2020.,4 Tumor jinak di Indonesia mencapai $74,8 \%$. Fibroadenoma Mammae (FAM) merupakan salah satu jenis tumor jinak payudara pada wanita muda yang berusia <25 tahun dan paling banyak terjadi. Jakarta Breast Center mengatakan $79 \%$ dari 2.495 pasien yang datang menderita FAM. Menurut Badan
Registrasi Kanker Perhimpunan Dokter Spesialis Patologi Indonesia (IAPI) dan Yayasan Kanker Indonesia (YKI) pada tahun 2010, terdapat 12/100.000 kasus pada wanita dan $1 \%$ pada pria. ${ }^{5,6}$ Distribusi usia pasien dengan tumor ganas payudara yang ada di RS MRCCC bulan Mei 2013-2014 paling banyak berusia 40-49 tahun sebanyak 64 kasus dari 164 responden yang ada. $^{7}$ Setelah itu, belum ada data di RS MRCCC Jakarta yang terbaru.

\section{METODE}

Jenis penelitian menggunakan metode penelitian deskriptif dengan studi retospektif dengan melihat data hasil laboratorium pasien yang melakukan pemeriksaan sitologi dan histopatologi, sehingga didapatkan hasil pemeriksaan pasien pada tahun 2018. Cara yang digunakan dalam memilih sampel yaitu dengan metode total sampling, yaitu semua subjek yang memenuhi kriteria pemilihan dimasukkan kedalam penelitian. Sebanyak 304 sampel berdasarkan kriteria inklusi dan eksklusi dari total keseluruhan pemeriksaan sitologi dan histopatologi pada pasien dengan keluhan benjolan pada payudara di RS Siloam. 
HASIL DAN PEMBAHASAN

\begin{tabular}{|c|c|c|c|c|c|c|}
\hline \multirow[b]{2}{*}{ Keterangan } & \multicolumn{2}{|c|}{ Non neoplasma } & \multicolumn{2}{|c|}{ Neoplasma Jinak } & \multicolumn{2}{|c|}{ Neoplasma Ganas } \\
\hline & Jumlah & $\begin{array}{c}\text { Persentase( } \\
\%)\end{array}$ & Jumlah & $\begin{array}{c}\text { Persentase } \\
(\%)\end{array}$ & Jumlah & $\begin{array}{c}\text { Persentase } \\
(\%)\end{array}$ \\
\hline \multicolumn{7}{|l|}{ Usia (Tahun) } \\
\hline $20-29$ & 4 & 1,3 & 25 & 8,4 & 7 & 2,3 \\
\hline $30-39$ & 9 & 3,0 & 25 & 8,4 & 23 & 7,7 \\
\hline $40-49$ & 3 & 1,0 & 23 & 7,7 & 64 & 21,5 \\
\hline $50-59$ & 4 & 1,3 & 3 & 1,0 & 64 & 21,5 \\
\hline $60-69$ & 0 & 0 & 5 & 1,7 & 23 & 7,7 \\
\hline $70-79$ & 1 & 0,3 & 1 & 0,3 & 14 & 4,7 \\
\hline $80-89$ & 1 & 0,3 & 2 & 0,6 & 3 & 1 \\
\hline \multicolumn{7}{|l|}{ Pemeriksaan } \\
\hline Histopatologi & 16 & 5,2 & 80 & 26,3 & 198 & 65,1 \\
\hline sistologi & 6 & 2 & 1 & 0,3 & 3 & 1 \\
\hline \multicolumn{7}{|l|}{ Sediaan } \\
\hline $\begin{array}{l}\text { FNAB (fine needle } \\
\text { aspiration biopsy) }\end{array}$ & 6 & 2 & 1 & 0,3 & 7 & 2,3 \\
\hline Mastektomi & 1 & 0,3 & 3 & 1 & 82 & 27 \\
\hline Lumpektomi & 15 & 4,9 & 77 & 25,3 & 112 & 36,8 \\
\hline \multicolumn{7}{|l|}{ Diagnosis } \\
\hline \multicolumn{7}{|l|}{ Non neoplasma } \\
\hline Kista payudara & 7 & 2,3 & & & & \\
\hline Mastitis & 13 & 4,3 & & & & \\
\hline \multicolumn{7}{|l|}{ Neoplasma jinak } \\
\hline Fibroadenoma mammae & & & 55 & 18 & & \\
\hline \multicolumn{7}{|l|}{ Fibrocystic change } \\
\hline Intraductal papiloma & & & 17 & 5,6 & & \\
\hline Tumor filodes jinak & & & 6 & 2 & & \\
\hline Penyakit fibrokistik & & & 3 & 1 & & \\
\hline Neoplasma ganas & & & 2 & 0,7 & & \\
\hline \multicolumn{7}{|l|}{ Karsinoma mammae } \\
\hline Tumor filodes ganas & & & & & 198 & 65,1 \\
\hline & & & & & 3 & 1 \\
\hline
\end{tabular}

Dari 304 laporan kasus yang merupakan pasien Rumah Sakit Siloam MRCCC Semanggi pada tahun 2018. Usia 40-49 tahun adalah kategori usia paling banyak menjadi sampel pada penelitian ini, yaitu sebanyak 90 (30,2\%) sampel. Hal ini sesuai dengan data WHO yang menunjukkan bahwa $78 \%$ kejadian kanker payudara terjadi pada wanita usia di atas 30-50 tahun. ${ }^{16,18,19,20}$ Kemungkinan kelompok usia ini mengalami penurunan fungsi sel dan jaringan dalam tubuh dapat mengakibatkan terjadinya penumpukan selsel yang lama akan membuat sulit untuk di perbaiki sehingga akan terjadi kerusakan sel di dalam tubuh. Secara bertahap daya tahan tubuh manusia makin rentan terhadap berbagai penyakit degenerative contoh nya kanker. ${ }^{21}$
Berdasarkan hasil pemeriksaan laboratorium didapatkan bahwa hasil pemeriksaan histopatologi lebih tinggi dibandingkan dengan pemeriksaan sitologi yaitu sebesar 294 (96,6\%) sampel dan 10 $(3,6 \%)$ sampel. Hal ini disebabkan pemeriksaan histopatologi merupakan pemeriksaan dengan pengambilan jaringan padat, yang berhubungan langsung dengan benjolan pada payudara, pemeriksaan ini membantu penegakan diagnosis secara tepat.

Neoplasma ganas menjadi nilai tertinggi yaitu tedapat sebanyak $201(66,1 \%)$ sampel dibandingkan dengan diagnosis lainnya. Selanjutnya, terdapat neoplasma jinak dengan angka kejadian sebanyak 83 $(27,3 \%)$ sampel dan angka kejadian paling rendah yaitu non neoplasma yaitu sebesar 
20 (6,6\%). Data ini memiliki kolerasi dengan data Riskesdas 2018 yang menunjukkan peningkatan dari prevalensi kanker dan tumor mencapai 1,79 per 1000 penduduk dibandingkan tahun 2013 yaitu 1,4 per 1000 penduduk. Data kanker payudara di Rumah Sakit Kanker Dharmais menduduki peringkat tertinggi sebesar $34,3 \%$ pada tahun $2018 .^{22,23}$

Untuk menegakkan diagnosis diperlukan pengambilan sampel jaringan. Berdasarkan

\section{KESIMPULAN}

Berdasarkan hasil penelitian dapat disimpulkan bahwa, tumor ganas terbanyak yaitu karsinoma mammae dengan jumlah 128 (43\%) pada rentang usia 40-59 tahun. Tumor jinak terbanyak yaitu fibroadenoma mammae dengan jumlah $50 \quad(16,8 \%)$

\section{DAFTAR PUSTAKA}

1. Heuther SE. McCance KL. Perubahan pada sistem reproduksi perempuan. Buku Ajar Patofisiologi. 2019. 2(6). 346-347

2. Price SA, Wilson LM. Payudara, anatomi dan fisilogi. Patofisiologi: Konsep klinis proses-proses penyakit. 2013. 2(6). 1301-1302.

3. Globocan 2020. WHO South-East Asia (SEARO). Diunduh dari : https://gco.iarc.fr/today/data/factsheets /populations/995-who-south-east-asiasearo-fact-sheets.pdf 21 Januari 2021

4. Globocan 2020. Indonesia. Diunduh dari:

https://gco.iarc.fr/today/data/factsheets /populations/360-indonesia-factsheets.pdf 21 Januari 2021

5. Aster KA. Sistem genitalia wanita dan payudara. Buku Ajar Patologi Robbins. 2013. 9. 694-695

6. Alini, Widya L. Faktor-faktor yang menyebabkan kejadian fibroadenoma mammae (FAM) pada pasien wanita yang berkunjung di poliklinik spesialis bedah umum RSUD Bengkalis. Jurnal Ners. 2018;2(1):1-10. data di atas tindakan lumpektomi paling banyak digunakan, yaitu sebanyak 204 (67\%) dibanding tindakan mastektomi dan FNAB. Berdasarkan penelitian tindakan lumpektomi lebih banyak digunakan karena lumpektomi dapat mengangkat massa tumor dengan menyeluruh, namun dapat mempertahankan bentuk payudara dibandingkan dengan tindakan mastektomi dan FNAB sendiri. ${ }^{24,25}$

sampel pada rentang usia 20-39 tahun. Non neoplasma terbanyak yaitu mastitis dengan jumlah 9 (3\%) pada rentang usia 30-38 tahun. Pemeriksaan terbanyak untuk mendiagnosis benjolan pada payudara adalah histopatologi dengan sediaan lumpektomi.

7. Aldilla A. Pola Subtipe Molekuler Pada Pasien Kanker Payudara Berdasarkan Hasil Pemeriksaan Imunohistokimia di RS MRCCC Siloam Hospitals Semanggi Tahun 2013-2014. Universitas Tarunegara Repository. 2015

8. Kementrian Kesehatan Republik Indonesia. Panduan Penatalaksanaan Kanker Payudara. 2015.p.1

9. Dyanti GAR, Suariyani NLP. Faktorfaktor keterlambatan penderita kanker payudara dalam melakukan pemeriksaan awal ke pelayanan kesehatan. Jurnal Kesehatan Masyarakat. 2016;11(2):276-84.

10. Raby A. Benign Breast Lumps. Bupa UK Heal. 2018;1(2):1-9.

11. Kumalasari DR. Laporan pendahuluan fibroadenoma mammae. UINAM Nurse. 2016;2(1):5-25.

12. Suyatno. Peran pembedahan pada tumor jinak payudara. Majalah Kedokteran Andalas. 2015;38(1):1227.

13. Taufiqurrahman M. Tumor mammae. Jurnal Kesehatan Khatulistiwa. 2017;3:1-38. 
14. Anggorowati L. Faktor risiko kanker payudara wanita. Jurnal Kesehatan Masyarakat.2013;8(2):102-8.

15. Wahidin M. Deteksi dini kanker leher rahim dan kanker payudara di Indonesia 2007-2014. Buletin Jendela Data dan Informasi Kesehatan. 2015;1:12-5.

16. Humaera R, Mustofa S. Diagnosis dan penatalaksanaan karsinoma mammae stadium 2. Jurnal Medula Universitas Lampung. 2017;7(2):103-7.

17. World Health Organization. Department of child and adolescent health and development. Mastitis: Penyebab \& penatalaksanaan. Jakarta: Widya Medika; 2001.

18. Irawan E. Faktor-faktor pelaksanaan sadari/Breast Self Examination (BSE) kanker payudara (Literature Review). Jurnal Keperawatan BSI. 2018;6(1).

19. Sihombing M, Sapardin AN. Faktor resiko tumor payudara pada perempuan umur 25-65 tahun di lima kelurahan kecamatan bogor tengah. Kementrian Kesehatan Republik Indonesia. 2014. 6-8.

20. Kamińska M, Ciszewski T, ŁopackaSzatan K, Miotła P. Breast cancer risk factors. Termedia Journal. 2015;14(3):196-202.
21. Yulianti, Iin dkk. Faktor-Faktor Risiko Kanker Payudara Rumah Sakit Ken Saras Semarang. Jurnal Kesehatan Masyarakat. Semarang. 2016;4(4):159164

22. Godet I, Gilkes DM. BRCA1 and BRCA2 mutations and treatments strategies for breast cancer. National Centre For Biotechnology Information. 2017;4(1):4-21.

23. Begam AJ, Jubie S, Nanjan MJ. Estrogen receptor agonist/antagonist in breast cancer therapy: A critical review. Bioorganic Chemistry. 2017;71:25774.

24. Kartika Ika, Maulani Heni, Sulastri Henny, Yuwono, Ekspresi protein HER-2/neu, status reseptor estrogen dan progesteron pada berbagai derajat keganasan karsinoma payudara duktal invasif wanita usia muda. Departemen Patologi Anatomi Fakultas Kedokteran Universitas Sriwijaya Palembang. 2016. 18. 35.

25. Han Z, Wei B, Zheng Y, Yin Y, Li K, Li S. Breast cancer multi-classification from histopathological images with structured deep learning model. Scientific Reports. 2017;7(1):1-10 